\title{
Oral Findings in Alagille Syndrome
}

\author{
A Case Report
}

\author{
Sabeeha Al-Mutawa ${ }^{a}$ Bapsy Mathews $^{a}$ Nathanael Salako ${ }^{b}$ \\ a Ministry of Health School Health Program and 'baculty of Dentistry, Kuwait University, Kuwait
}

\section{Key Words}

Alagille syndrome - Liver disease - Dentition . Hypoplasia, dental

\begin{abstract}
Objective: To highlight the role of dental practitioners in the management of children with liver diseases. Clinical Presentation: A 13-year-old girl with Alagille syndrome presented with oral manifestation of end-stage liver disease that needed liver transplant. The dentition showed hypoplastic lesions and severe discoloration. The gingiva was inflamed and edematous due to poor oral hygiene and possibly to the medication the child was placed on to reduce graft rejection. Conclusion: Dental considerations should be incorporated in the overall management of children with liver disease and transplant. Consultation with a dental practitioner should be sought before, during and after treatment of such cases.
\end{abstract}

Copyright $\odot 2002$ S. Karger AG, Basel

\section{Introduction}

Alagille syndrome is a condition that can lead to endstage liver disease, usually requiring treatment by a liver transplant. As with any transplant, the greatest complication is the possibility of rejection. One of the major causes of rejection apart from incompatibility of the tissues is preoperative and postoperative infection. The oral cavity has been shown to harbor many pathogenic bacteria that could produce bacteremia with the potential of causing severe and acute infection in other organs of the body.

Alagille syndrome is a genetic disorder that is inherited as an autosomal dominant trait located on chromosome $20 p$ [1]. A deletion or mutation of a single copy of the human gene Jagged 1 has been shown to be the underlying genetic defect in the syndrome [2, 3]. Alagille et al. [4] in 1975 first described this disease as a syndrome characterized by hepatic hypoplasia, associated with characteristic facies, vertebral malformations, and retardation of physical, mental and sexual development as well as cardiac murmurs. Since then, many more in-depth studies have been published on the various characteristics of the syndrome. Emerrick et al. [5] studied 92 patients with Alagille syndrome to determine the frequencies of clinical manifestations and to correlate such findings with the outcome of the disease. They showed that $85 \%$ of the patients had paucity of interlobular ducts, $96 \%$ cholestasis, $97 \%$ cardiac murmur, $51 \%$ butterfly vertebrae, $78 \%$ posterior embryotoxon and $96 \%$ characteristic facies. Other features included renal disease as well as intracranial bleeding and stroke (49 and 14\%, respectively).

Pediatric liver transplant has now become an accepted therapy for end-stage liver disease [6] although children with Alagille syndrome may or may not require liver transplantation. The most common factors contributing to the decision for transplantation are complications such as bone fracture, pruritus and severe xanthoma [7].

In this paper we present the role of the dental practitioner in the overall management and oral findings in a child with Alagille syndrome.

\begin{tabular}{ll}
\hline KARGER & ( ) 2002 S. Karger AG, Basel \\
Fax +4161306 1234 & 1011-7571/02/0113-0161\$18.50/0 \\
$\begin{array}{l}\text { E-Mail karger@karger.ch } \\
\text { www.karger.com }\end{array}$ & $\begin{array}{l}\text { Accessible online at: } \\
\text { www.karger.com/journals/mpp }\end{array}$
\end{tabular}

Prof. Nathanael Salako

Faculty of Dentistry, Kuwait University

PO Box 24923

13110 Safat (Kuwait)

Tel. +965 2664502, ext. 7108, Fax +965 5326049, E-Mail natsal@hsc.kuniv.edu.kw 


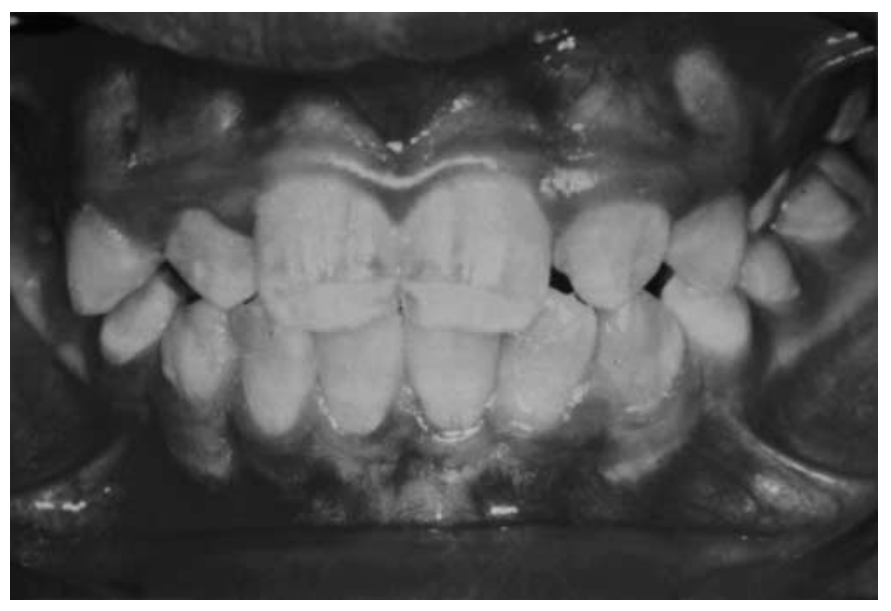

Fig. 1. Intrinsic discoloration and hypoplasia of the dentition.

\section{Case Report}

A 13-year-old girl presented for dental treatment at the school dental clinic for checkup. Medical history revealed that she was jaundiced at birth and at 60 days after, she underwent laparotomy, intraoperative choleogram and a liver biopsy. The result of the biopsy revealed paucity of interlobular bile ducts. An echocardiogram also showed the presence of peripheral pulmonary artery stenosis. She also presented with hepatosplenomegaly but without ascites and edema. Otherwise, all other vital signs were normal. At age 3, she had pain in her right hip with an accompanying limp of the right foot. There was no history of trauma or fever. She was put on a waiting list for a liver transplant. Prior to her transplant, she developed severe rickets with extensive bowing of the tibias and suffered a fracture of the right femur. At age 11, she underwent an orthotopic liver transplant. She was placed on cyclosporin, prednisolone, Zestril and multivitamins.

Her dental development was normal for her chronological age. The maxillary lateral incisors were conically shaped (fig. 1). All her teeth showed a grayish intrinsic discoloration with focal areas of white and yellow patches and enamel hypoplasia with pronounced horizontal and vertical developmental lines (fig. 1). The discoloration, however, was more severe in the maxillary and mandibular anterior teeth (fig. 2) than others. There was no carious lesion and with the exception of the maxillary lateral incisors, all the teeth had normal morphological characteristics. Although the oral mucosa was normal with no evidence of discoloration, the gingivae, especially around the anterior teeth, showed evidence of inflammation and mild gingival swelling (fig. 1, 2). The oral hygiene was fair.

Her dental management so far has involved improving of oral hygiene and placing fissure sealant on the molars. She is to have treatment to improve the aesthetics of the maxillary anterior teeth as soon as she is disposed to such treatment.

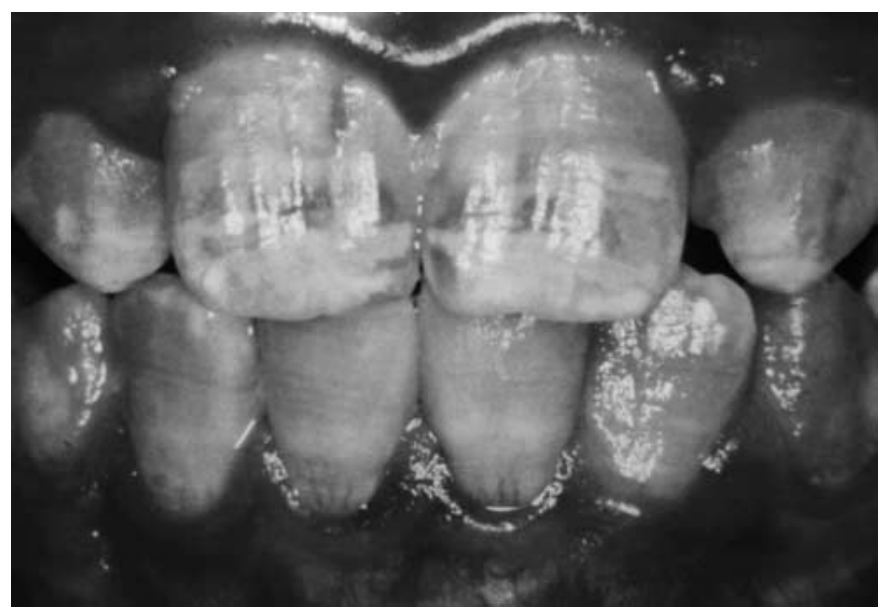

Fig. 2. Severe intrinsic discoloration and enamel hypoplasia of the anterior teeth.

\section{Discussion}

The major complications after liver transplantation are related to graft rejections, immunosuppression, side effects of the agent used for immunosuppression, and excessive bleeding after injury resulting from poor liver function and/or the effects of anticoagulation medication [8]. One of the causes of graft rejection and early death after liver transplantation is infection from a variety of sources. The oral cavity harbors numerous pathogenic and opportunistic species which, when out of their normal environment, can cause serious infections [9]. In fact, oral bacteria have been incriminated in systemic diseases such as pneumonia, gastritis, peptic ulcers and infective endocarditis [10-13].

Dental infections, therefore, may pose great risks for patients especially after liver transplant. Consequently it is recommended that dental examination and consultation should be carried out at different management phases to evaluate the oral health status of such patients (table 1). Preoperatively, all carious teeth should be restored or extracted; the periodontal tissue should be healthy and the oral hygiene should be improved. All dental treatment should be carried out in collaboration with the physician who will advise on drug selection, the use of antibiotic prophylaxis and control of bleeding in cases requiring tooth extraction or surgery.

Postoperatively, patients also require regular dental checkups because of the continuous use of immunosuppressive drugs. One of the side effects of these immunosuppressive agents is the suppression of bone marrow, which may result in leukopenia, thrombocytopenia or 
Table 1. Dental procedures and rationale for patients with end-stage liver disease before transplantation

\begin{tabular}{ll}
\hline Procedure & Rationale \\
\hline $\begin{array}{l}\text { Before transplantation } \\
\text { Medical investigation }\end{array}$ & $\begin{array}{l}\text { Bleeding tendencies, medication type could affect oral } \\
\text { health and dental procedures } \\
\text { Reduction of oral bacterial load } \\
\text { Oral hygiene instruction }\end{array}$ \\
$\begin{array}{l}\text { Treatment and prevention of plaque-related disease } \\
\text { Chlorhexidine mouthwash }\end{array}$ & $\begin{array}{l}\text { Clinical antiplaque and antibacterial agent } \\
\text { Reduction of foci of infection in the oral cavity }\end{array}$ \\
Extraction of all grossly carious teeth & Reduction of bacteremia \\
Antibiotic cover for invasive dental procedures & Reduction of oral bacterial load \\
After transplantation & Reduction of oral bacterial load/oral health maintenance \\
Oral hygiene instruction & Improvement of aesthetics and function \\
Professional prophylaxis & Monitoring medication and general health \\
Restorative and cosmetic dental treatment &
\end{tabular}

anemia, any of which may predispose patients to excessive bleeding tendencies and opportunistic infections such as candidiasis.

Cyclosporin has also been associated with increased incidence of drug-induced gingival overgrowth, which may not only impair oral aesthetics but may also lead to gingival inflammation and periodontal tissue damage [14]. Regular dental prophylaxis and drug modulation, in consultation with the physician, can prevent the development of this condition.

\section{Conclusion}

Dental consultation, examination and treatment should be required for patients being prepared for liver transplant or having end-stage liver disease. The dentist should institute an aggressive preventive regimen and consult with the transplant surgeon before performing any invasive dental procedures. After transplantation, a regimen of regular dental visits is essential to monitor patients' oral health status and possible adverse effects of the immunosuppressants.

\section{References}

1 Bukley DA, Higgins EM, du Vivier AW: Resolution of xanthomas in Alagille syndrome after liver transplantation. Pediatr Dermatol 1998; 15:199-202.

2 Oda T, Elkahloun AG, Pike BL, Okajima K, Krantz ID, Genin A, Piccoli Da, Meltzer PS, Spinner NB, Collins FS, Chandrasekharappa SC: Mutations in the human Jagged 1 gene are responsible for Alagille syndrome. Nat Genet 1997; 16:235-242.

3 Li L, Krantz ID, Deng Y, Genin A, Banta AB, Collins CC, Qi M, Trask BJ, Kuo WL, Cochran J, Costa T, Pierpont ME, Rand EB, Piccoli DA, Hood L, Spinner NB: Alagille syndrome is caused by mutations in human Jagged 1, which encodes a ligand for Notch1. Nat Genet 1997; $16: 243-251$.
4 Alagille D, Oddievre M, Gautier M, Dommergues JP: Hepatic ductular hypoplasia associated with characteristic facies, vertebral malformations, retarded physical, mental and sexual development, and cardiac murmur. J Pediatr 1975;86:63-71.

5 Emerrick KM, Rand EB, Goldmuntz E, Krant ID, Spinner NB, Piccoli DA: Features of Alagille syndrome in 92 patients: Frequency and relation to prognosis. Hepatology 1996;29: 822-829.

6 Andrews W, Sommerauer J, Roden J, Anderson J, Conlin C, Moore P: 10 years of liver transplantation. J Pediatr Surg 1996;31:619624.

7 Hoffenberg EJ, Narkewicz MR, Sondheimer JM, Smith DJ, Silverman A, Sokol RJ: Outcome of syndromic paucity of interlobular bile ducts (Alagille syndrome) with onset of cholestasis in infancy. J Pediatr 1995; 127:220-224.

8 Little JW, Rhodus NL: Dental treatment of the liver transplant patient. Oral Surg Oral Med Oral Pathol 1992;73:419-426.
9 Roberts MC: Antibiotic resistance in oral/ respiratory bacteria. Crit Rev Oral Biol Med 1998;9:522-540.

10 Limeback $H$ : The relationship between oral health and systemic infections among elderly residents of chronic care facilities. A review. Gerodontology 1988;7:131-137.

11 Scannapeico FA, Mylotte JM: Relationship between periodontal disease and cardiovascular disease. J Periodontol 1996;67:1114-1122.

12 Shames B, Krajden S, Fuska M: Evidence for the occurrence of the same strain of Campylobacter pylori in the stomach and dental plaque. J Clin Microbiol 1989;27:2849-2850.

13 Desai HG, Gill HH, Shankara K: Dental plaque: A permanent reservoir of Helicobacter pylori? Scand J Gastroenterol 1991;26:12051208.

14 Seymour RA, Jacobs DJ: Cyclosporin and the gingival tissue. J Clin Periodontol 1992;19:111. 